\title{
TIPE KEMATIAN SEL HeLa SETELAH PAPARAN EKSTRAK ETANOLIK CURCUMA LONGA
}

\author{
Suryani Hutomo, Chandra Kurniawan \\ Bagian Mikrobiologi, Fakultas Kedokteran Universitas Kristen Duta Wacana \\ Fakultas Kedokteran Universitas Kristen Duta Wacana \\ Korespondensi: suryanihutomo_drg@yahoo.com
}

\begin{abstract}
ABSTRAK
Kunyit (Curcuma longa) merupakan tanaman yang dapat tumbuh di daerah tropis dan sub tropis. Di Indonesia, kunyit menyebar secara merata di seluruh daerah. Kurkumin yang merupakan unsur utama kunyit, merupakan antioksidan yang kuat. Penelitian terdahulu melaporkan bahwa ekstrak etanolik Curcuma longa menyebabkan kematian sel sejumlah separuhnya pada sel HeLa setelah dipapar selama 24 jam dengan konsentrasi 184,5 $\mu \mathrm{g} / \mathrm{ml}$, tetapi tipe kematian sel dan mekanismenya belum jelas. Tujuan penelitian ini adalah untuk mengkaji pengaruh ekstrak Curcuma longa pada tipe kematian sel HeLa. Sel HeLa (5 x10 ${ }^{4} \mathrm{sel} /$ well) dikultur dalam RPMI 1640 semalam sebelum stimulasi. Ekstrak etanol kunyit (150 $\mu \mathrm{g} / \mathrm{ml}$ ) ditambahkan pada kultur HeLa dan diinkubasi selama 24 jam dalam medium tanpa antibiotik. Analisis tipe kematian sel HeLa dilakukan dengan menggunakan mikroskop fluoresence setelah double staining acridine orange/ethidium bromide (AO/EB). Doksorubisin $(0,5625 \mu \mathrm{g} / \mathrm{ml})$ digunakan sebagai kontrol positif induksi apoptosis. Hasil penelitian menunjukkan bahwa ekstrak Curcuma longa menyebabkan kematian sel berupa apoptosis pada sebagian besar sel HeLa yang ditandai dengan perubahan warna sel menjadi orange. Analisa statistik menunjukkan perbedaan yang bermakna antara kelompok kontrol negatif dengan kelompok stimulasi dalam jumlah sel yang mengalami apoptosis. Disimpulkan bahwa ekstrak Curcuma longa mampu menginduksi apoptosis pada sebagian besar sel HeLa.
\end{abstract}

Kata kunci: ekstrak Curcuma longa, sel HeLa, apoptosis 


\title{
DEATH TYPE OF HeLa CELL'S AFTER EXPOSURE TO CURCUMA LONGA ETANOLIC EXTRACT
}

\author{
Suryani Hutomo, Chandra Kurniawan \\ Bagian Mikrobiologi, Fakultas Kedokteran Universitas Kristen Duta Wacana \\ Fakultas Kedokteran Universitas Kristen Duta Wacana \\ Correspondence: suryanihutomo_drg@yahoo.com
}

\begin{abstract}
Curcuma mostly found in areas with tropical and sub-tropical climate. In Indonesia, curcuma can be found in almost all regions and areas. Curcumin, which is curcuma's main constituent, is a potent anti oxidant. Previous study reported that $184 \mu \mathrm{g} / \mathrm{ml}$ Curcuma longa etanolic extract caused cell death in a half amount of HeLa cells after 24 hours stimulation, but the types and mechanism of cells death is unclear. The aim of this study is to study the effect of ml Curcuma longa etanolic extract to HeLa cell death types. HeLa cells $\left(5 \times 10^{4}\right.$ cells/well) were cultured in complete RPMI 1640 overnight before stimulation. $150 \mu \mathrm{g} / \mathrm{ml}$ Curcuma longa etanolic extract were added to the culture of HeLa cells and were incubated for 24 hours in antibiotic-free of culture medium. HeLa cells cell death types analysis was performed under fluoresence microscope after acrydine orange/ ethidium bromide staining. Doksorubisin $(0,5625 \mathrm{mg} / \mathrm{ml})$ was used as positive control in this study. The results demonstrated that Curcuma longa extract caused apoptosis in most Hela cells indicated by orange color. Statical analysis showed there was significant difference between controls and treatment groups. It was concluded that Curcuma longa extract inducted apoptosis in most of Hela cells.
\end{abstract}

Keyword: Curcuma longa extract, HeLa cells, apoptosis 


\section{PENDAHULUAN}

Kunyit

(Curcuma

longa) merupakan tanaman Asia Tenggara. Di India dan Asia Tenggara, rimpang kunyit biasa digunakan sebagai bumbu makanan dan pewarna makanan. Selain itu, kunyit juga menjadi tanaman obat, yang secara tradisional biasa digunakan untuk penyembuhan luka. Warna kuning kunyit berasal dari yang pigmen polifenol yang larut dalam lemak, yang dikenal dengan nama kurkuminoid. Kurkuminoid menyusun sekitar 2-9\% dari kandungan kunyit. Beberapa kandungan kurkuminoid yang bisa ditemukan pada kunyit adalah kurkumin, demethoxykurkumin dan bisdemethoxykurkumin. Kurkumin yang merupakan unsur utama dari kunyit, merupakan antioksidan yang kuat, sama seperti vitamin $\mathrm{E}$ dan betacarotene, sehingga kunyit bisa menjadi pilihan dalam proteksi hepar dan proses penuaan dini.

Kurkumin mempunyai efek antioksidan, antiviral dan antifungal serta aksi anti inflamasi melalui penghambatan beberapa molekul penting yang berperan dalam inflamasi. Efek anti-inflamasi kunyit merupakan kombinasi dari 3 mekanisme, yaitu menurunkan produksi histamin, meningkatkan produksi dan memperpanjang daya kerja cortisol yang dihasilkan oleh kelenjar adrenal yang memiliki efek anti-inflamasi serta meningkatkan sirkulasi darah, sehingga mampu mengeluarkan toksintoksin (celular waste dan inflamatory compound) yang sering terperangkap di dalam sendi-sendi kecil.

Beberapa penelitian melaporkan bahwa kurkumin mampu menghambat pertumbuhan beberapa tipe sel kanker. Mekanisme kurkumin menginduksi apoptosis diduga melalui penghambatan beberapa cell-signaling pathway. Target-targetnya antara lain transcription factor, oncogens, dan signaling protein. Kurkumin berperan dalam kontrol siklus sel dan stimulasi apoptosis melalui regulasi p16 dan p53. ${ }^{1}$ Penelitian terdahulu melaporkan bahwa kurkumin menyebabkan kematian sel sebanyak separuh dari jumlah sel yang diinduksinya dengan dosis 184,5 $\mu \mathrm{g} /$ $\mathrm{ml}$ (data tidak dipublikasikan). Dalam penelitian tersebut belum diketahui tipe kematian sel yang disebabkannya. Tujuan penelitian ini adalah untuk mengkaji pengaruh ekstrak etanolik Curcuma longa terhadap tipe kematian sel HeLa.

\section{METODE PENELITIAN}

\section{Ekstraksi Curcuma longa}

Kunyit didapatkan dari daerah Bantul, Yogyakarta. Ekstraksi dilakukan dengan metode maserasi. Metode ini dilakukan dengan cara serbuk kunyit (simplisia) yang didapatkan dari rimpang kunyit usia 9 bulan, dimasukkan ke dalam wadah, setelah itu ditambahkan pelarut etanol dengan perbandingan $10: 1$. Simplisia direndam selama 24 jam dengan melakukan pengadukan secara berkala, setelah itu dilakukan penampungan filtrat. Ampas yang didapatkan dari penyaringan kemudian direndam kembali dengan menggunakan etanol 96\%. Prosedur ini dilakukan sebanyak 3 kali. Setelah filtrat didapatkan maka dilakukanlah evaporasi dengan menggunakan evaporator hingga dihasilkan ekstrak semi padat etanol rimpang kunyit. Ekstrak kemudian keringkan dalam oven bersuhu $40^{\circ} \mathrm{C}$. 


\section{Kultur sel HeLa}

Sel HeLa ditumbuhkan dalam medium RPMI $1640^{2}$ yang disuplementasi dengan 10\% FBS, $100 \mathrm{IU} / \mathrm{ml}$ penisilin, $10 \mu \mathrm{g} / \mathrm{ml}$ streptomisin dalam suhu $37^{\circ} \mathrm{C}$ dengan kadar $\mathrm{CO} 2$ 5\%. Flask yang berisi sel diinkubasi untuk mendapatkan sejumlah sel yang dibutuhkan (konfluen). Sel HeLa dipanen dengan cara menambahkan 1-2 $\mathrm{ml}$ tripsin 0,25\% ke dalam flask dan ditunggu beberapa saat. Sel HeLa kemudian dipindahkan ke conical tube dan ditambahkan medium RPMI hingga volume $10 \mathrm{ml}$ kemudian disentrifuge selama 5 menit dengan kecepatan $2000 \mathrm{rpm}$.

Supernatan kemudian dibuang, pelet diresuspensi dalam $1 \mathrm{ml}$ medium dan dihitung jumlahnya menggunakan bilik hitung. Suspensi sel dipindahkan pada 24 well-plate yang sudah diberi coverslip, ditambahkan sejumlah medium hingga memperoleh konsentrasi sel sebesar $5 \times 10^{4}$ sel/100 $\mathrm{hl}$ dan siap digunakan.

\section{Analisis tipe kematian sel HeLa}

Sel HeLa dikultur pada 24 wellplate yang diberi coverslip pada tingkat kepadatan $5 \times 10^{4}$ sel/well. Ekstrak curcumin dilarutkan dengan dimethylsulfoxide (DMSO) dalam konsentrasi awal $1 \mathrm{mg} / \mathrm{ml}$, selanjutnya dilakukan aliquot dan disimpan pada suhu $-20^{\circ} \mathrm{C}$. Larutan curcumin dalam DMSO diencerkan dalam RPMI tanpa antibiotik hingga konsentrasi final $150 \mu \mathrm{g} / \mathrm{ml}$. Setelah semalam kultur, sel dipapar dengan curcumin pada konsentrasi $150 \mu \mathrm{g} / \mathrm{ml}$ selama 24 jam. Sebagai kontrol negatif, sel HeLa dikultur dalam RPMI tanpa curcumin, sedangkan sebagai kontrol positif, sel HeLa dikultur dalam RPMI dan dipapar dengan doxorubisin dengan konsentrasi 0,5625 $\mu \mathrm{g} / \mathrm{ml}$. Coverslip yang telah dilekati sel Hela kemudian ditempatkan pada glass slide yang telah ditetesi dengan acridine orange/ethidium bromide (AO/EB). Pengamatan tipe kematian sel HeLa setelah paparan curcumin dilakukan menggunakan mikroskop fluoresence untuk mengidentifikasi dan menghitung jumlah sel yang mengalami kematian per 10 lapangan pandang.

\section{ANALISIS STATISTIK}

Hasil penghitungan jumlah sel HeLa yang mengalami kerusakan dikuantifikasi dalam persen yang merupakan data representatif dari 3 kali eksperimen. Tes normalitas dan homogenitas dilakukan menggunakan tes Shapiro-Wilk dan Levene. Hasil analisa menunjukkan bahwa data terdistribusi normal dan homogen dengan signifikansi $\mathrm{p} \mathrm{0,05}$. persentase sel yang mengalami kematian dianalisa menggunakan Student t-test. Post Hoc Multiple Comparison dilakukan untuk menganalisa mean differences diantara grup. Signifikansi statistik didapatkan dengan harga $\mathrm{p}<0,05$.

\section{HASIL PENELITIAN}

Hasil penelitian menunjukkan bahwa sel HeLa yang normal berwarna hijau (gb.A). Warna sel HeLa berubah setelah sel dipapar curcumin. Tampak sel yang mengalami apoptosis berwarna orange dan yang mengalami nekrosis berwarna merah (gb B). 


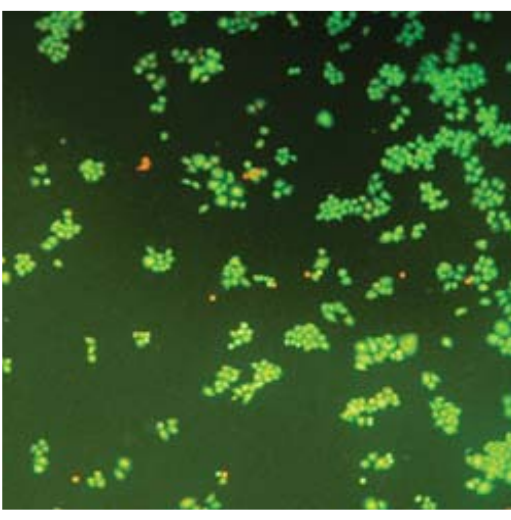

A

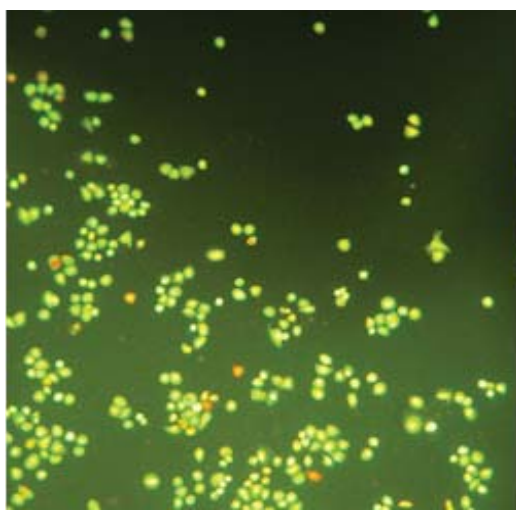

B

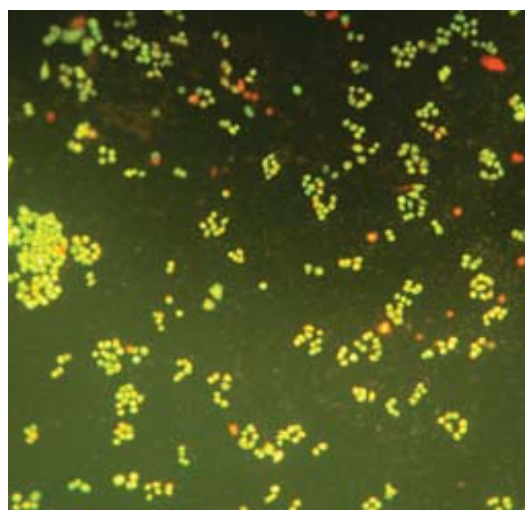

C

Gb.1. Sel HeLa tanpa paparan kurkumin tampak berwarna hijau (A). Perubahan warna terjadi pada sel HeLa yang dipapar kurkumin dengan konsentrasi $150 \mu \mathrm{g} / \mathrm{ml}$ (B), sel hidup (hijau), nekrosis (merah), apoptosis (orange). Sel HeLa dipapar doxorubicin (C) sebagai kontrol posistif apoptosis.

Dari hasil penghitungan prosentase didapatkan bahwa setelah dipapar kurkumin rata-rata jumlah sel yang mengalami apoptosis sebesar
28,87\%, nekrosis $12.15 \%$ dan sel hidup sebesar $58,98 \%$.

Hasil representatif dari 3 kali eksperimen (Tabel 1).

Tabel 1. Rerata dan deviasi standar persentase sel HeLa setelah dipapar kurkumin

\begin{tabular}{lllllrl}
\hline Nomor sampel & \multicolumn{3}{l}{ GRUP KONTROL } & \multicolumn{4}{c}{ GRUP PERLAKUAN } \\
\cline { 2 - 7 } & Hijau & Merah & Orange & Hijau & Merah & Orange \\
\hline 1 & 99,12 & 0,32 & 0,56 & 62,25 & 8,73 & 29,02 \\
2 & 96,64 & 1,88 & 1,48 & 58,73 & 10,21 & 31,06 \\
3 & 96,85 & 1,73 & 1,42 & 56,53 & 16,32 & 27,15 \\
4 & 98,21 & 0,63 & 1,16 & 58,42 & 13,34 & 28,24 \\
Rerata & 97,71 & 1,14 & 1,16 & 58,98 & 12,15 & 28,87 \\
DS & 1,17 & 0,78 & 0,42 & 2,39 & 3,38 & 1,85 \\
\hline
\end{tabular}

Data Shapiro-Wilk test digunakan untuk menganalisa normalitas data. Harga p untuk kelompok kontrol, stimulasi ekstrak $150 \mathrm{\mu g} / \mathrm{ml}$ (hijau merah dan orange) $>0.05$. Nilai $\mathrm{p}$ mengindikasikan bahwa data terdistribusi normal. Selanjutnya Levene test digunakan untuk menguji homogenitas data. Nilai p untuk semua data lebih besar dari a $(0,05)$ yang artinya data homogen.
Guna menguji pengaruh konsentrasi kurkumin terhadap persentase sel hidup, nekrosis dan apoptosis dilakukan student $t$ - test dan didapatkan nilai $\mathrm{p}$ 0,00 yang artinya terdapat perbedaan yang bermakna pada tipe persentase sel yang mengalami kerusakan (Tabel 2). 
Tabel 2. Student t-test

\begin{tabular}{|c|c|c|c|c|c|}
\hline \multicolumn{2}{|r|}{$\mathrm{t}$} & \multicolumn{4}{|c|}{ t-test for Equality of means } \\
\hline & & $\mathrm{df}$ & $\begin{array}{c}\text { Sig. } \\
(2 \text {-tailed })\end{array}$ & $\begin{array}{l}\text { Mean Dif- } \\
\text { ference }\end{array}$ & \\
\hline Number_cell & Equal variances assumed & $-32,540$ & 6 & ,000 & $-27,71250$ \\
\hline (Green) & $\begin{array}{l}\text { Equal variances not as- } \\
\text { sumed }\end{array}$ & $-32,540$ & 3,387 & ,000 & $-27,71250$ \\
\hline Number_cell & Equal variances assumed & $-6,348$ & 6 & ,001 & $-11,01000$ \\
\hline (Red) & $\begin{array}{l}\text { Equal variances not as- } \\
\text { sumed }\end{array}$ & $-6,348$ & 3,319 & ,004 & $-11,01000$ \\
\hline Number_cell & Equal variances assumed & 29,137 & 6 & ,000 & 38,72250 \\
\hline (Orange) & $\begin{array}{l}\text { Equal variances not as- } \\
\text { sumed }\end{array}$ & 29,137 & 4,369 & ,000 & 38,72250 \\
\hline
\end{tabular}

\section{DISKUSI}

Hasil penelitian menunjukkan bahwa ekstrak etanolik Curcuma longa dapat menyebabkan kematian pada sel HeLa yang berupa apoptosis dan nekrosis. Prosentase sel yang mengalami apoptosis lebih besar daripada sel yang mengalami nekrosis. Pewarnaan dengan metode double staining menggunakan acridine orange dan ethidium bromide dapat membedakan sel yang hidup, sel apoptosis dan sel nekrosis. Sel hidup akan tampak memiliki inti sel dengan bentuk normal dan berwarna hijau. Sel yang mengalami apoptosis akan memiliki inti sel berwarna oranye dengan bentuk terkondensasi atau terfragmentasi. Acridine orange mengandung gugus kation sehingga dapat berinteraksi dengan DNA sel hidup yang bersifat anionik membentuk garam terdisosiasi dan dapat memasuki sel dan mewarnai inti sel menjadi hijau. Ethidium bromide tidak dapat menembus membran sel yang utuh, sehingga hanya dapat mewarnai sel mati karena terjadi penurunan integritas membran dan bersifat tidak pemiabel terhadap senyawa yang masuk. Dengan demikian, ethidium bromide merusak rantai double helix dan menghambat replikasi, reparasi, dan rekombinasi DNA. Ethidium bromide juga lebih mendominasi warna yang dihasilkan acridine orange. $^{2}$

Apoptosis adalah kematian sel yang terprogram dan dapat terjadi pada keadaan fisiologis maupun patologis. ${ }^{3}$ Pada keadaan fisiologis, apoptosis terjadi untuk menjaga homeostasis jaringan pada hewan dewasa, pada sistem imun dimana sel B dan sel T mati selama proses maturasi serta untuk menghilangkan sel yang terinfeksi maupun sel yang rusak. ${ }^{4}$ Pada penelitian ini juga didapatkan hasil sama, dimana pada kelompok kontrol negatif didapatkan sel yang mengalami apoptosis $(1,16 \%)$ dan nekrosis $(1,14 \%)$. Apoptosis yang patologis didapatkan pada penyakit Alzheimers, Parkinson dan stroke. ${ }^{4}$ 
Kesulitan deteksi apoptosis dan nekrosis dengan menggunakan metode double staining $\mathrm{AO} / \mathrm{EB}$ adalah zat bersifat toksik terhadap sel, sehingga pengamatan harus cepat. Paparan AO/ EB yang terlalu lama akan menyebabkan sel nekrosis. Berdasarkan hal tersebut maka penting untuk dilakukan penelitian lebih lanjut tentang mekanisme seluler dan molekuler kurkumin dalam menginduksi apoptosis pada sel HeLa yang merupakan model sel kanker epitelium.

\section{KESIMPULAN}

Kurkumin menyebabkan kematian sel HeLa yang sebagian besar berupa apoptosis.

\section{UCAPAN TERIMA KASIH}

Ucapan Terimakasih disampaikan kepada Laboratorium Pengujian dan Penelitian Terpadu (LPPT) Universitas Gadjah Mada Yogyakarta.

\section{DAFTAR PUSTAKA}

1. Wilken Reason. Curcumin: A review of anti-cancer properties and therapeutic activity in head and neck squamous cell carcinoma. Molecular cancer. 2011. (diakses dari : http:// www.molecular-cancer.com/ content/10/1/12).

2. Ribel D, Goldstein NB, Norris DA, Shellman YG. A simple technique for quantifying apoptosis in 96-well plates. BMC Biotechnology , 2005. 5:12.

3. Elmore S. Apoptosis : A review of programmed cell death. Toxicol Pathol 2007. 35(4): 495-516.

4. Porth CM and Matfin G. 2009. Pathophysiology. Concepts of Altered Health States. $8^{\text {th }}$ ed. Lippincott Williams \& Wilkins. Philadelphia. USA. 2012: 94-111. 